\title{
Nutritional risk factors in hospitalized nonagenarian patients
}

\author{
Fatores de risco nutricional em pacientes nonagenários hospitalizados
}

\section{DOI: 10.37111/braspeni.2020352009}

Ludiane Alves do Nascimento'

Grasiela K. P. Andrade

Juliana Bonfleur Carvalho

Ana Lucia Chalhoub Chediac Rodrigues ${ }^{3}$

Ariane Nadólskis Severine ${ }^{4}$

\section{Unitermos:}

Idoso de 80 Anos ou mais. Desnutrição. Estado nutricional.

\section{Keywords:}

Aged, 80 and over. Malnutrition. Nutritional status.

\section{Mailing Address:}

Hospital Sírio-Libanês - Nutrição

Ludiane Alves do Nascimento

Rua Dona Adma Jafet, 91 - São Paulo, SP, Brazil CEP 01308-050

E-mail: ludiane.nascimento@hsl.org.br

Submission:

March 12, 2020

\section{Accepted for publication}

July 2, 2020

\section{RESUMO}

Introdução: Em 2050, estima-se que o grupo de indivíduos com 90 anos ou mais crescerá cinco vezes em relação a 2010. Nos idosos, o processo da doença pode contribuir com piora do estado nutricional. Portanto, este artigo tem como objetivo associar o estado nutricional de indivíduos nonagenários ao diagnóstico da internação, massa muscular, via de alimentação e desfecho clínico. Pois, apesar do aumento progressivo e das particularidades dessa população, poucos estudos foram realizados considerando os nonagenários. Método: Estudo transversal, que incluiu pacientes acima de 90 anos internados no Hospital Sírio Libanês. Foram coletados: circunferência da panturrilha $(C P)$, índice de massa corporal $(I M C)$, via de alimentação e diagnóstico médico. $A$ triagem nutricional foi realizada através da Mini Avaliação Nutricional (MAN) - versão reduzida. Resultados: Foram avaliados 79 pacientes, com idade mediana de 92 anos, IMC de 22,6 kg/ $\mathrm{m}^{2}$ e internação hospitalar de 13 dias; $59,5 \%(\mathrm{n}=47)$ eram do sexo feminino. A frequência de desnutrição segundo o IMC foi de $54,4 \%$. Houve relação positiva $(71,4 \%)$ entre a $C P<31 \mathrm{~cm}$ e baixo peso nos pacientes de acordo com o IMC $(p=0,032)$. A desnutrição (classificada pela MAN) esteve significativamente associada a disfagia $(77,4 \%)(p=0,003)$, uso de suplementos $(p=0,002)$ e terapia nutricional enteral $(p=0,005)$. A mortalidade $(25,8 \%)$ também foi significativamente relacionada à desnutrição, demonstrando que o estado nutricional contribuiu para o pior desfecho clínico $(p=0,042)$. Conclusão: A disfagia apresentou relação positiva com desnutrição, por ser uma condição que dificulta a ingestão alimentar. $\mathrm{O}$ uso de suplemento e maior indicação de terapia nutricional enteral tiveram relação positiva com a desnutrição, pois são condutas indicadas para melhorar o estado nutricional, demonstrando que ações específicas de assistência nutricional poderão contribuir para um melhor estado nutricional do nonagenário.

\section{ABSTRACT}

Introduction: In 2050, we estimate that the population of individuals who are 90 years of age or older will be five times higher than that in 2010 . Among elderly people, the disease process can contribute to a worsening nutritional status. This article aims to examine the associations among nutritional status and initial diagnoses, muscle mass, routes of feeding, and clinical outcomes. Despite the progressive increase in this population and their particularities, few studies have been conducted among nonagenarians. Methods: This was a cross-sectional study that included patients over 90 years old admitted to Hospital Sírio Libanês. The following parameters were assessed: calf circumference $(\mathrm{CC})$, body mass index (BMI), routes of feeding and medical diagnosis. Nutritional screening was performed using the Mini Nutritional Assessment (MNA). Results: A total of 79 patients were assessed, and they had a median age of 92 years, a median BMI of $22.6 \mathrm{~kg} / \mathrm{m}^{2}$ and median hospital stay of 13 days. A total of $59.5 \%$ of the patients $(n=47)$ were female. The frequency of malnutrition (as assessed by the BMI) was $54.4 \%$. There was a positive relationship $(71.4 \%)$ between $C C<31 \mathrm{~cm}$ and underweight (as assessed by the BMI) $(\mathrm{p}=0.032)$. Malnutrition (classified using the MNA) was significantly associated with dysphagia $(77.4 \%)(p=0,003)$, the use of supplements $(p=0.002)$ and enteral nutrition therapy $(p=0.005)$. Mortality $(25.8 \%)$ was also significantly related to malnutrition, showing that nutritional status contributed to poor clinical outcomes in patients $(p=0.042)$. Conclusion: Dysphagia had a positive relationship with malnutrition because it is a condition that affects food intake. The use of supplements and a higher indication for enteral nutritional therapy both had a positive relationship with malnutrition because they are conducts indicated to improve nutritional status, showing that specific nutrition assistance strategies for this age group can contribute to improved nutritional status in nonagenarians.

1. Nutritionist, Specialist in Parenteral and Enteral Nutrition - BRASPEN, Hospital Sírio Libanês, São Paulo, SP, Brazil.

2. Nutritionist, Postgraduate in Applied Human Nutrition and Nutritional Therapy, Hospital Sírio Libanês, São Paulo, SP, Brazil.

3. Nutritionist, Master in Management for Competitiveness - Health Line - Fundação Getúlio Vargas, Hospital Sírio Libanês, São Paulo, SP, Brazil.

4. Nutritionist, Master of Health Sciences - Universidade Federal de São Paulo (Unifesp), Hospital Sírio Libanês, São Paulo, SP, Brazil. 


\section{INTRODUCTION}

In 2050, we estimate that the population of individuals who are 90 years of age or older will be five times higher than that in 2010; we also estimate that this population will grow faster than other segments of the population and will account for $0.72 \%$ of the total population ${ }^{1,2}$.

The Brazilian population has showed an aging trend over the last few years; according to the National Household Sample Survey conducted by the Brazilian Institute of Geography and Statistics (IBGE), in 2017, there were more than 30.2 million elderly people in Brazil, which was 4.8 million more than in $2012^{3}$.

Current data point indicate that the prevalence of malnutrition among hospitalized elderly people ranged from 35\% to $65 \%{ }^{4}$. In elderly people, the disease process more often contributes to worsening nutritional status and results in several anatomical and functional alterations, thereby affecting the individual's health status and increasing the risk of complications ${ }^{5}$.

Poor nutritional status is associated with increased morbidity and mortality, increased length of hospitalization, more frequent readmission, and increased healthcare costs ${ }^{6}$.

Therefore, in the hospital, it is necessary to apply specific nutritional screenings for this age group. The short version of the MNA is a nutritional assessment tool that can be used for elderly patients older than 60 years of age. The instrument assesses the initial risk of malnutrition in a rapid and simple manner, allowing for early intervention and treatment ${ }^{7}$.

Malnutrition also leads to changes in body composition, including the loss of lean mass. The circumferences of the extremities, including calf circumference (CC), have been found to be very useful for evaluating the health and nutritional status of elderly persons, and these measures can provide valuable information on muscle-related disability and physical function ${ }^{8}$.

CC is a simple and universally applicable anthropometric measure that has been used as a surrogate marker of muscle mass in population studies and has good correlations with appendicular skeletal muscle mass and the skeletal muscle index (SMI) as measured by dual-energy X-ray absorptiometry (DXA). The European Working Group on Sarcopenia in Older People (EWGSOP) includes CC as an option for an anthropometric measure to identify the loss of muscle mass?. The $\mathrm{CC}$ is also an effective predictor of the follow-up mortality risk among older patients. CC has the strongest predictive ability among elderly people over 65 years of age ${ }^{8}$.

When a patient is at risk of malnutrition or malnutrition, nutritional supplements can help in the recovery of nutritional status. Supplementation or enrichment of the diet can be accomplished by adding natural foods or specific nutrients to meals (e.g., powdered protein modules, maltodextrin, medium chain triglycerides) to increase the caloric and protein density of meals and drinks ${ }^{4}$.

This article aims to examine the associations among nutritional status and initial diagnoses, muscle mass, routes of feeding, and clinical outcomes. Despite the progressive increase in this population and their characteristic nature, few studies have been conducted among nonagenarians.

\section{METHODS}

A cross-sectional study that included patients who were at least 90 years old was performed between January and December 2018, in the hospital wards and semi-intensive and intensive care units (ICUs) of a private hospital in the city of São Paulo (Hospital Sírio Libanês).

\section{Research Procedures}

Parameters such as age, anthropometric measures (CC, weight and height), gender, routes of feeding, and admission diagnosis were assessed.

The short-form MNA was also administered. Scores between 12 and 14 indicate elderly individuals with a normal nutritional status; scores between 8 and 11 indicate individuals with a nutritional risk; and scores between 0 and 7 indicate individuals who are malnourished ${ }^{7}$.

The CC of the left leg was measured using a nonelastic tape measure at the most protruding portion. Only a circumference equal to or above $31 \mathrm{~cm}$ was considered adequate for both genders ${ }^{7}$. Measurements were not taken in patients who were bedridden for more than 15 days. After this period, atrophy of the lower limbs occurs due to a lack of mobility, and thus, the measure would reflect only muscle mass depletion ${ }^{10}$. Furthermore, patients were excluded from the sample if they had edema in the lower limbs or if they used pneumatic boots, both of which made it impossible to measure the CC.

Weight was measured with a Toledo ${ }^{\circledR}$ scale with an accuracy of $50 \mathrm{~g}$, and height was measured using a stadiometer coupled to the scale. For bedridden patients, weight was measured using a Linet bed scale, with an accuracy of 100 $\mathrm{g}$, and height was estimated using the Chumlea equation. Based on these data, the BMI was calculated and classified according to the OPAS criteria, $2002^{11}$.

Nutritional screening was performed, and anthropometric measures were obtained by previously trained professionals with five years of experience.

The patients were classified according to the admission diagnosis, main comorbidities and the presence of dysphagia. 
The routes of feeding were classified according to whether patients were receiving oral nutritional therapy (ONT), enteral nutritional therapy (ENT) or parenteral nutritional therapy (PNT). We also assessed whether patients consumed nutritional supplements.

The research was carried out after approval by the hospital's ethics and research committee, and informed consent forms were obtained from all included patients.

\section{Statistical Analysis}

The categorical data were described and presented as absolute (n) and relative frequencies (\%) and analyzed using Pearson's chi-square test or Fisher's exact test as appropriate. The frequency of nutritional risk and malnutrition was estimated as the proportion of elderly people at nutritional risk and malnutrition.

The continuous variables were described as medians and percentiles. Mann-Whitney tests were used to compare the groups. A value of $\alpha \leq 0.05$ was considered significant for the whole study. The SPSS 21.0 program from IBM ${ }^{\circledR}$ was used for the analyses.

The dependent variable was malnutrition as assessed by the MNA. Logistic regression was adjusted for age and gender.

\section{RESULTS}

A total of 79 patients were assessed; they had a median age of 92 (91 to 94), a median BMI of 22.6 (19.7-27.1) $\mathrm{kg} / \mathrm{m}^{2}$ and a median hospital stay of 13 (7-29) days. A total of $59.5 \%$ of the patients $(n=47)$ were females, and $40.5 \%$ $(n=32)$ were males.

Regarding the nutritional status assessment, more than half of the patients were malnourished according to either their BMI or the MNA (Table 1).

The most frequent diseases were systemic arterial hypertension and respiratory diseases; comorbidities included diabetes mellitus and dyslipidemia (Table 1).

This study revealed a statistically significant relationship $(p=0.032$ ) between $C C<31 \mathrm{~cm}$ and underweight (as assessed by the BMI).

With regard to routes of feeding, significant relationships between oral feeding and adequate nutritional status and between enteral nutrition and malnutrition were observed. The use of supplements and the presence of dysphagia were more frequent among patients who were malnourished. The relationship between malnutrition and mortality was significant, with the number of deaths doubling in malnourished patients compared to non-malnourished patients (Table 2).

The presence of dysphagia predicted the occurrence of malnutrition (as assessed by the MNA) (Table 3).
Table 1 - Characterization according to nutritional status, routes of feeding and clinical outcomes.

\begin{tabular}{lccc}
\hline Classification & & $\mathrm{n}$ & $\%$ \\
\hline Nutritional Status & Underweight & 43 & 54.4 \\
\hline BMI & Normal weight & 15 & 19.0 \\
& Overweight & 11 & 13.9 \\
& Obesity & 10 & 12.7 \\
\hline MNA & Normal nutritional status & 8 & 10.1 \\
& At risk of malnutrition & 40 & 50.6 \\
\hline CC (cm) & Malnourished & 31 & 39.2 \\
& $>=31$ cm & 19 & 24.0 \\
& $<31$ cm & 22 & 28.0 \\
& Bedridden> 15 days & 19 & 24.0 \\
& Edema or use of & 19 & 24.0 \\
& pneumatic boots & & \\
\hline
\end{tabular}

\section{Routes of}

feeding

\begin{tabular}{lcc} 
Oral & 60 & 75.9 \\
Enteral & 18 & 22.8 \\
Parenteral & 1 & 1.3 \\
\hline
\end{tabular}

\section{Admission}

diagnosis

Respiratory

31

39.2

Genitourinary

11.4

Infection

Gastrointestinal $\quad 7$

Tract

Acute

Cardiopathy

Other**

19

24.0

Presence of

Dysphagia

\section{Comorbidities}

\begin{tabular}{lll} 
DM & 26 & 32.9 \\
SAH & 43 & 54.4 \\
DLP & 26 & 32.9 \\
\hline
\end{tabular}

\section{Outcome}

\begin{tabular}{llc} 
Discharge & 68 & 86.10 \\
Death & 11 & 13.9 \\
\hline
\end{tabular}

$\mathrm{BMl}=$ body mass index; $\mathrm{CC}$ = calf circumference; $\mathrm{DM}=$ diabetes mellitus; $\mathrm{DLP}=$ dyslipidemia; MNA = Mini Nutritional Assessment; $\mathrm{SAH}=$ systemic arterial hypertension. *impossibility of measurement of the calf circumference; **neurological disorders, autoimmune, musculoskeletal, oncological diseases and traumas. 
Table 2 - Characterization of the population considering the classification of nutritional risk screening according to the MNA.

\begin{tabular}{|c|c|c|c|c|c|c|c|}
\hline & \multicolumn{2}{|c|}{ Normal nutritional status } & \multicolumn{2}{|c|}{ At risk of malnutrition } & \multicolumn{2}{|c|}{ Malnourished } & $\begin{array}{c}\text { Pearson's X } \\
\text { Sig. }\end{array}$ \\
\hline \multicolumn{8}{|l|}{ Comorbidities } \\
\hline $\mathrm{DM}$ & 4 & 50.0 & 13 & 32.5 & 9 & 29.0 & 0.529 \\
\hline SAH & 4 & 50.0 & 23 & 57.5 & 16 & 51.6 & 0.855 \\
\hline DLP & 3 & 37.5 & 14 & 35.0 & 9 & 29.0 & 0.833 \\
\hline Respiratory Infection & 4 & 50.0 & 14 & 35.0 & 13 & 41.9 & 0.676 \\
\hline Genitourinary Infection & 2 & 25.0 & 3 & 7.5 & 4 & 12.9 & 0.343 \\
\hline Gastrointestinal Infection & 0 & 0.0 & 6 & 15.0 & 1 & 3.2 & 0.145 \\
\hline Acute Cardiopathy & 1 & 12.5 & 7 & 17.5 & 5 & 16.1 & 0.939 \\
\hline Oral Nutrition & 7 & 87.5 & 37 & 92.5 & 19 & 61.3 & 0.004 \\
\hline Enteral Nutrition & 1 & 12.5 & 4 & 10.0 & 13 & 41.9 & 0.005 \\
\hline Use of Supplements & 1 & 14.3 & 9 & 24.3 & 14 & 66.7 & 0.002 \\
\hline Presence of Dysphagia & 2 & 25.0 & 17 & 42.5 & 24 & 77.4 & 0.003 \\
\hline Death & 1 & 12.5 & 2 & 5.0 & 8 & 25.8 & 0.042 \\
\hline
\end{tabular}

$\mathrm{DM}$ = diabetes mellitus; DLP = dyslipidemia; MNA = Mini Nutritional Assessment; SAH = systemic arterial hypertension.

Table 3 - Logistic regression for malnutrition risk according to the MNA.

\begin{tabular}{lccc}
\hline Presence of malnutrition (MNA) & Sig. & Adjusted odds ratio & 95\% C.I. for EXP (B) \\
\hline Presence of dysphagia & & Lower & Upper \\
\hline
\end{tabular}

MNA = Mini Nutritional Assessment.

\section{DISCUSSION}

According to the Brazilian Hospital Nutritional Assessment Survey (IBRANUTRI), the prevalence of malnutrition among Brazilian elderly people was $48.1 \%^{12}$.

Similar results were found in this study. However, the values were close to the upper limit (54.4\%) because we included only nonagenarian patients; older elderly individuals have an increased risk of underweight and decreased risks of overweight and obesity ${ }^{13}$. Aging induces important changes in muscle mass and body fat distribution, and it is associated with decreasing height, which can influence the cutoff points for $\mathrm{BMI}^{14}$.

According to the study by Sass \& Marcon ${ }^{13}$, who assessed anthropometric measures in elderly residents of an urban area in southern Brazil, elderly individuals older than 80 years of age presented a lower average BMI than elderly individuals between 60 and 80 years of age across both genders. In the study by Pereira et al. ${ }^{15}$, age was negatively associated with
$\mathrm{BMI}$, demonstrating that older age was associated with a decreasing BMI. In our study, the median BMI was $22.6 \mathrm{~kg} /$ $\mathrm{m}^{2}$, which is classified as a underweight by the OPAS, 2002 criteria $^{1}$. However, this value suggests that for individuals older than 90 years of age, there must be a specific classification for $\mathrm{BMI}$ with decreased cutoff points.

Regarding gender, the high frequency of females was consistent with findings from other studies conducted in patients in this age range. These data suggest that the mortality rates of different genders follow different paths during aging and that longevity in women is less dependent on genetics than longevity in men?.

When evaluating the results, we observed a statistically significant relationship $(p=0.032)$ between $C C<31 \mathrm{~cm}$ and underweight (Figure 1). Studies showed that elderly individuals with underweight presented a loss of lean mass, which was accentuated by aging ${ }^{16}$. 


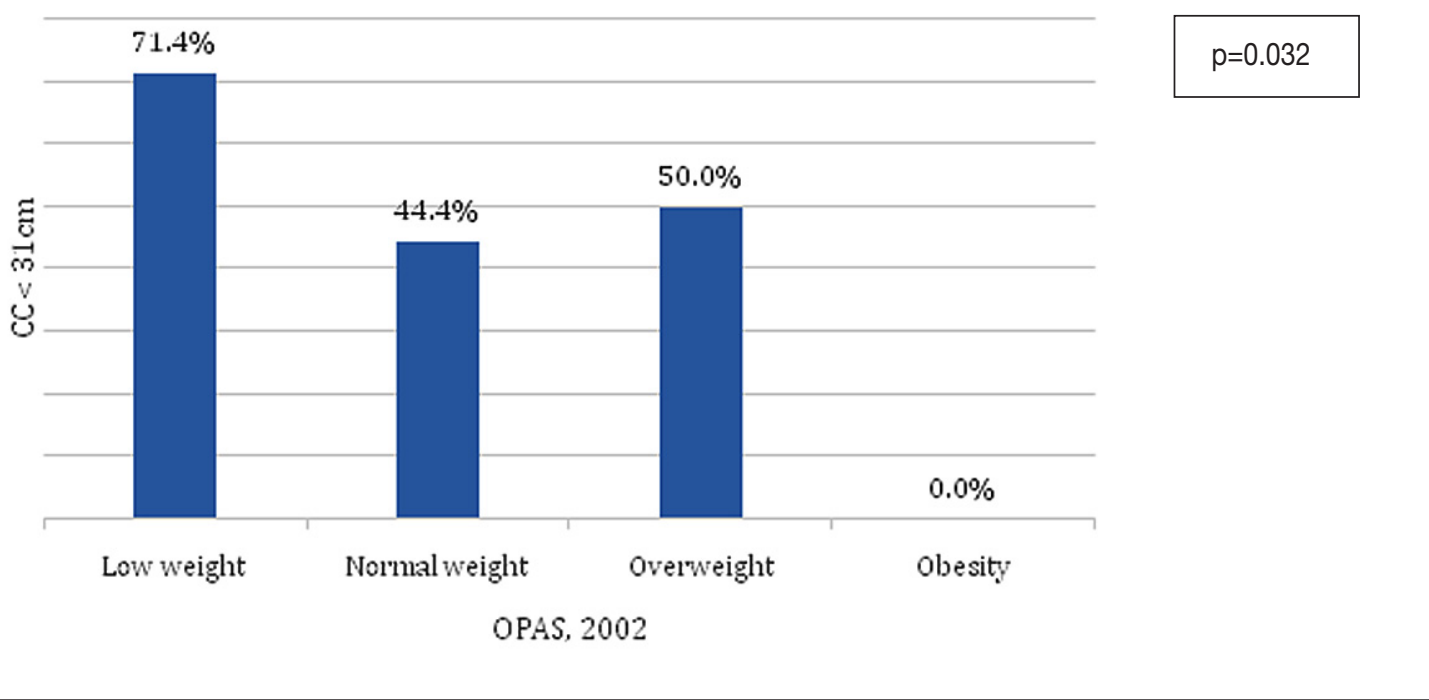

Figure 1 - Relationship between calf circumference (CC) and nutritional status (NS).

According to Mello et al. ${ }^{17}$, the CC is highly effective in detecting underweight, nutritional risk and malnutrition. The measurement of the CC has allowed for an adequate nutritional diagnosis and the implementation of adequate interventions for the maintenance and/or recovery of the nutritional state, as this measure has an impact on clinical outcomes (i.e., elderly individuals with a $\mathrm{CC}<31 \mathrm{~cm}$ presented a 2.24 times greater chance of death than elderly individuals with a $C C>31 \mathrm{~cm})^{16}$. Tsai and $\mathrm{Chang}^{8}$ observed that elderly persons with low BMI, low mid-arm circumference (MAC) or low CC had a higher mortality risk than those with a normal BMI or normal circumferences.

We also observed a high percentage of normal weight (44.4\%) and overweight (50.0\%) patients who had reduced calf circumference; although these findings were not statistically significant, this reduced CC may increase the risk of mortality. Larger circumferences of the extremities, especially the CC, have been observed to have protective health effects. An inverse association between upper CC and mortality has previously been observed in males and females as reported in the National Health and Nutrition Examination Survey I and $\|^{8}$.

Regarding nutrition, $41.9 \%$ of the patients who received enteral nutrition were malnourished. This relationship between malnutrition and enteral nutrition can be explained by the fact that there is a strong recommendation for elderly individuals with a risk of undernourishment to start enteral nutrition therapy early in case the strategies used to increase oral ingestion have no effect ${ }^{18}$.

The use of supplements was frequent in malnourished patients $(66.7 \%, p=0.02)$. There is strong evidence for supplementation in elderly individuals with increased nutritional risk, as insufficient food intake is the primary cause of malnutrition and supplementation is one of the most effective strategies to increase the calorie and protein supply 19,20.

In hospitalized patients, this recommendation specifically aims to improve food intake and body composition and reduce the risks of complications, rehospitalization and functional decline, thereby enhancing the elderly individual's quality of life ${ }^{18}$. A systematic review of 36 randomized controlled trials and a series of meta-analyses demonstrated that patients who received greater protein intake through supplements had relatively low frequencies of complications and readmissions as well as increased hand grip strength and weight ${ }^{19}$.

It was verified that the presence of dysphagia predicted malnutrition $(O R=2.6)$. This was observed in $77.4 \%$ of the elderly individuals who had difficulty swallowing. This result is in line with data reported by Sura et al. ${ }^{21}$ and López et al. ${ }^{22}$. This association exists because dysphagia makes food intake difficult, thereby increasing the risk of malnutrition, and malnutrition makes rehabilitation therapies for processes involved in swallowing difficult ${ }^{21}$.

An effective strategy in these cases can be to change the consistency of the food to compensate for the patient's functional limitations ${ }^{23}$. However, modified diets are generally associated with a reduction in the quantity of food and drinks offered, and food with a changed consistency can have a relatively high water content, which reduces its caloric content ${ }^{22}$.

Finally, in this study, the relationship between malnutrition and mortality was also significant $(p=0.042)$, suggesting that nutritional status may have contributed to the clinical outcomes of the patients. Malnutrition alone is associated with prolonged hospitalization, increased hospital costs, more 
rehospitalization events, increased morbidity and increased mortality ${ }^{24}$. In a study conducted with patients with an average age of 78.1 years, malnutrition was associated with seventeen out of the twenty causes of death examined ${ }^{25}$.

The limitations of this study included the sample size and the absence of an analysis of hospital complications that could have influenced the nutritional status and clinical outcomes of the patients.

\section{CONCLUSION}

Among the diseases, dysphagia had a positive relationship with malnutrition because it is a condition that affects food intake. The use of supplements and a higher indication for enteral nutritional therapy both had a positive relationship with malnutrition, as these factors indicate a need to improve nutritional status, showing that specific nutrition assistance strategies can contribute to improved nutritional status in nonagenarians.

\section{REFERENCES}

1. Hotta VT. Considerações sobre pacientes centenários. Arq Bras Cardiol. 2015;28(1):1-2.

2. Hoogendijk EO, Van der Noordt M, Onwuteaka-Philipsen BD, Deeg DJH, Huisman M, Enroth L, et al. Sex differences in healthy life expectancy among nonagenarians: A multistate survival model using data from the Vitality $90+$ study. Exp Gerontol. 2019;116:80-5.

3. Instituto Brasileiro de Geografia e Estatística. Número de idosos cresce 18\% em 5 anos e ultrapassa 30 milhões em 2017. [cited 2019 Jun 05]. Available from: https://agenciadenoticias.ibge.gov.br/agencia-noticias/2012-agencia-de-noticias/ noticias $/ 20980$

4. Gonçalves TJM, Horie LM, Gonçalves SEAB, Bacchi MK, Bailer MC, Barbosa-Silva TG, et al. Diretriz BRASPEN de terapia nutricional no envelhecimento. BRASPEN J. 2019;34(supl. 3):2-58.

5. Cederholm T, Bosaeus I, Barazzoni R, Bauer J, Van Gossum A, Klek S, et al. Diagnostic criteria for malnutrition: an ESPEN consensus statement. Clin Nutr. 2015;34(3):335-40.

6. Correia MITD, Perman MI, Waitzberg DL. Hospital malnutrition in Latin America: a systematic review. Clin Nutr. 2017;36(4):958-67.

7. Kaiser MJ, Bauer JM, Ramsch C, Uter W, Guigoz Y, Cederholm $\mathrm{T}$, et al. Validation of the Mini Nutritional Assessment shortform (MNA-SF): a practical tool for identification of nutritional status. J Nutr Health Aging. 2009;13(9):782-8.

8. TsaiAC, Chang TL. The effectiveness of BMI, calf circumference and mid-arm circumference in predicting subsequent mortality risk in elderly Taiwanese. Br J Nutr. 2011;105(2):275-81.
9. Real GG, Frühauf IR, Sedrez JHK, Dall'Aqua EJF, Gonzalez MC. Calf circumference: a marker of muscle mass as a predictor of hospital readmission. JPEN J Parenter Enteral Nutr. 2018;42(8):1272-9.

10. Boechat JCS, Manhães FC, Gama Filho RV, Istoé RSC. A síndrome do imobilismo e seus efeitos sobre o aparelho locomotor do idoso. Inter Science Place. 2015;1(22):89-107.

11. Organización Panamericana de la Salud. División de Promoción y Protección de la Salud. Encuesta multicéntrica salud bienestar y envejecimiento (SABE) en América Latina el Caribe: informe preliminar. [cited $2019 \mathrm{Feb} 22$ ]. Available from: https://iris.paho. org/handle/10665.2/45890

12. Waitzberg DL, Caiaffa WT, Correia MI. Hospital malnutrition: the Brazilian national survey (IBRANUTRI): a study of 4000 patients. Nutrition. 2001;17(7-8):573-80.

13. Sass A, Marcon SS. Comparação de medidas antropométricas de idosos residentes em área urbana no sul do Brasil, segundo sexo e faixa etária. Rev Bras Geriatr Gerontol. 2015;18(2):361-72.

14. Seidell JC, Visscher TL. Body weight and weight change and their health implications for the elderly. Eur J Clin Nutr. 2000;54(suppl. 3):S33-9.

15. Pereira IFS, Spyrides MHC, Andrade LMB. Estado nutricional de idosos no Brasil: uma abordagem multinível. Cad Saúde Pública. 2016;32(5): e00178814.

16. Cruz-Jentoft AJ, Bahat G, Bauer J, Boirie Y, Bruyère O, Cederholm T, et al. Sarcopenia: revised European consensus on definition and diagnosis. Age Ageing. 2019;48(1):16-31.

17. Mello FS, Waisberg J, Silva MLN. Calf circumference is associated with the worst clinical outcome in elderly patients. Geriatr Gerontol Aging. 2016;10(2):80-5.

18. Volkert D, Beck AM, Cederholm T, Cruz-Jentoft A, Goisser $\mathrm{S}$, Hooper L, et al. ESPEN guideline on clinical nutrition and hydration in geriatrics. Clin Nutr. 2019;38(1):10-47.

19. Cawood AL, Elia M, Stratton RJ. Systematic review and metaanalysis of the effects of high protein oral nutritional supplements. Ageing Res Rev. 2012;11(2):278-96.

20. Beard JR, OfficerA, Carvalho IA, Sadana R, PotAM, Michel JP, et al. The World Report on Ageing and Health: a policy framework for healthy ageing. Lancet. 2016;387(10033):2145-54.

21. Sura L, Madhavan A, Carnaby G, Crary MA. Dysphagia in the elderly: management and nutritional considerations. Clin Interv Aging. 2012;7:287-98.

22. López MIF, Ortí JER, Vela EC, Monte CG, Bernal VSB, Sanz RN. Los factores relacionados con la mortalidad en pacientes con disfagia ayudan en la toma de decisiones dietéticas y nutricionales. Nutr Hosp. 2015;31(2):820-8.

23. Najas M. I Consenso Brasileiro de Nutrição e Disfagia em pacientes hospitalizados. Barueri: Minha Editora; 2011.

24. Álvarez-Hernández J, Planas Vila M, León-Sanz M, García de Lorenzo A, Celaya-Pérez S, García-Lorda P, et al. Prevalence and costs of malnutrition in hospitalized patients; the PREDyCES Study. Nutr Hosp. 2012;27(4):1049-59.

25. Söderström L, Rosenblad A, Thors Adolfsson E, Bergkvist L. Malnutrition is associated with increased mortality in older adults regardless of the cause of death. Br J Nutr. 2017;117(4):532-40.

Institution where the study was developed: Hospital Sírio Libanês, São Paulo, SP, Brazil.

Conflict of interest: The authors declare that they have no conflicts of interest. 